At-Tarbawi: Jurnal Pendidikan, Sosial dan Kebudayaan

Volume 6 Nomor 2 Tahun 2019

doi: $10.32505 /$ tarbawi.v6i2.1268

\title{
Upaya Meningkatkan Hasil Belajar Kimia melalui Model Numbered Heads Together di SMAN 1 Sungai Raya
}

\author{
Muhammad Baihaki \\ Guru SMAN 1 Sungai Raya \\ baihaki@gmail.com
}

\begin{abstract}
This study aims to examine the extent to which the Numbered Heads Together (NHT) learning model can improve student learning outcomes. The subjects of this study were 17th grade X.1 semester II 2014/2015 academic year students, consisting of 6 male students and 11 female students. This research took place in 2 cycles, each cycle consisting of planning, action, observation, and reflection. Data obtained in this study include student learning outcomes taken from giving daily test questions given at the end of the cycle, the ability of teachers in learning taken from the observation sheet, student activities in learning taken from the observation sheet, and data about student reflection on lessons learned from the questionnaire at the end of each meeting. Indicators of success in this study are: (1) if $\geq 70 \%$ of the total students are categorized as complete with the criteria of completion of learning if the value of the evaluation results in cycles $I$ and $I I, \geq 70$, (2) if student activities in learning $\geq 70 \%$ are measured by look at the student observation sheet. The results of the study in the first cycle showed the average value of student learning outcomes of 65.29 and the percentage of mastery learning at $58.82 \%$. Student activity $61.36 \%$, percentage of teacher ability $68.33 \%$. While the results of research in the second cycle the average value of student learning outcomes by 75.88 and the percentage of mastery learning by $88.24 \%$. Student activity was $84.09 \%$, and the percentage of teacher ability by $85 \%$. From this study, it was concluded that using the NHT learning model could improve the learning outcomes of chemistry and class X.1 student activities in semester II of the 2014/2015 academic year on the subject matter of nomenclature of compounds and reaction equations.
\end{abstract}

Keywords: Learning Outcomes, Models, Numbered Heads Together (NHT)

\begin{abstract}
Abstrak
Penelitian ini bertujuan untuk mengkaji sejauh mana model pembelajaran Numbered Heads Together (NHT) dapat meningkatkan hasil belajar siswa. Subjek penelitian ini adalah siswa kelas X.1 semester II tahun pelajaran 2014/2015 yang berjumlah 17 siswa, terdiri dari 6 siswa putra dan 11 siswa putri. Penelitian ini berlangsung dalam 2 siklus yang masingmasing siklus terdiri atas tahap perencanaan, tindakan,observasi, dan refleksi. Data yang diperoleh dalam penelitian ini meliputi: hasil belajar siswa yang diambil dari pemberian soal ulangan harian yang diberikan pada akhir siklus, kemampuan guru dalam pembelajaran yang diambil dari lembar observasi, aktivitas siswa dalam pembelajaran yang diambil dari lembar observasi, dan data tentang refleksi siswa terhadap pembelajaran yang diambil dari angket pada setiap akhir pertemuan. Indikator keberhasilan pada penelitian ini adalah: (1) apabila $\geq 70 \%$ dari jumlah siswa berkategori tuntas dengan kriteria tuntas belajar apabila nilai hasil evaluasi pada siklus I dan II, $\geq 70$, (2) apabila aktivitas siswa dalam pembelajaran $\geq 70 \%$ yang diukur dengan melihat lembar observasi siswa. Hasil penelitian pada siklus I menunjukkan nilai rata-rata hasil belajar siswa sebesar 65,29 dan persentase ketuntasan belajar sebesar 58,82\%. Aktivitas siswa 61,36\%, persentase kemampuan guru 68,33\%. Sedangkan hasil penelitian pada siklus II nilai rata-rata hasil belajar siswa sebesar 75,88 dan persentase ketuntasan belajar sebesar 88,24\%. Aktivitas siswa 84,09\%, dan persentase
\end{abstract}


kemampuan guru sebesar 85\%. Dari penelitian ini diperoleh kesimpulan bahwa dengan menggunakan model pembelajaran NHT dapat meningkatkan hasil belajar kimia dan aktivitas siswa kelas X.1 semester II tahun pelajaran 2014/2015 pada materi pokok tata nama senyawa dan persamaan reaksi.

Kata Kunci: Hasil Belajar, Model, Numbered Heads Together (NHT) 


\section{A. Pendahuluan}

Tugas utama siswa yang ada di sekolah adalah mengikuti semua mata pelajaran yang diajarkan oleh guru. Salah satu mata pelajaran yang diajarkan di SMA adalah mata pelajaran kimia. Setiap materi pelajaran kimia yang diajarkan, guru memberikan soal-soal untuk mengetahui perkembangan kemajuan belajar siswa. Siswa dianggap tuntas mengikuti pelajaran kimia apabila telah memperoleh nilai sama atau lebih dari nilai kriteria ketuntasan minimal (KKM). KKM adalah nilai kriteria ketuntasan minimal yang harus diperroleh siswa setelah mengikuti mata pelajaran yang diberikan oleh guru.Mata pelajaran kimia adalah mata pelajaran yang di ajarkan di kelas X, dilanjutkan di kelas XI IPA dan di kelas XII IPA.

Pelajaran kimia mempunyai karateristik sama dengan IPA. Karakteristik tersebut adalah objek ilmu kimia, cara memperoleh serta kegunaannya. Kimia adalah ilmu yang mencari jawaban atas pertanyaan apa, mengapa dan bagaimana gejala-gejala alam yang berkaitan dengan komposisi, struktur dan sifat, perubahan, dinamika dan energetika. Oleh sebab itu mata pelajaran kimia di SMA mempunyai beberapa tujuan, antara lain melibatkan ketrampilan, dan penalaran yang berdasarkan sikap ilmiah dalam menguasai konsep-konsep kimia dan saling keterkaitannya serta menerapkannya dalam kehidupan sehari-hari. Ada dua hal yang berkaitan dengan kimia yang tidak terpisahkan yaitu kimia sebagai produk dan kimia sebagai proses (kerja ilmiah) (Depdikbud, 2014).

Dalam proses pembelajaran kimia masih sering dijumpai adanya kecenderungan siswa yang tidak mau bertanya kepada guru meskipun mereka sebenarnya belum mengerti tentang materi yang disampaikan. Tetapi ketika guru menanyakan bagian mana yang belum mereka mengerti seringkali siswa hanya diam, dan setelah guru memberikan soal latihan barulah guru mengerti bahwa sebenarnya ada bagian dari materi yang belum dimengerti siswa. Kondisi kelas X.1 SMA Negeri 1 Sungai Raya, berjumlah 17 siswa relatif heterogen, baik dari segi ekonomi, kemampuan akademik, kreatifitas maupun sarana yang dimilikinya. 
Berdasarkan segi kepemilikan buku yang dimiliki siswa cukup kecil. Selain itu berdasarkan pengalaman guru, didapati suasana kelas yang monoton pada setiap pembelajaran dilaksanakan, terlihat dari rendahnya kemampuan siswa untuk bertanya dan menjawab pertanyaan, nilai hasil belajar rendah, dengan persentase siswa yang tuntas belajar hanya berkisar antara $30-50 \%$ saja pada setiap ulangan dilaksanakan. Salah satu materi kimia yang diajarkan di kelas $\mathrm{X}$ adalah tata nama senyawa dan persamaan kimia. Nilai KKM untuk materi tersebut adalah 70. Nilai siswa yang diperoleh pada pertemuan pertama (pra siklus) sangat rendah. Berdasarkan nilai pra siklus siswa untuk materi ini, dari 17 siswa yang ada di kelas X1 hanya 3 (tiga) siswa yang memperoleh nilai yang tuntas. Berdasarkan pengalaman, hasil observasi dan diskusi dengan beberapa guru, rendahnya hasil belajar siswa selama ini disebabkan karena proses pembelajaran kimia masih didominasi oleh guru sehingga keaktifan siswa dalam kelas masih kurang.

Berdasarkan permasalahan tersebut penulis merasa berkewajiban untuk mencari dan menerapkan sebuah metode pembelajaran yang dapat meningkatkan hasil belajar kimia. Hal ini menjadi sebuah permasalahan yang mendasari penulis untuk mencari dan menerapkan sebuah model yang bertujuan untuk memecahkan masalah yang dihadapi siswa, model tersebut adalah model Numbered Heads Together (NHT). Dipilihnya model tersebut karena NHT adalah suatu pendekatan yang dikembangkan untuk melibatkan lebih banyak siswa dalam menelaah materi yang tercakup dalam suatu pelajaran dan mengecek pemahaman mereka terhadap isi pelajaran tersebut sebagai gantinya mengajukan pertanyaan kepada seluruh kelas. Model pembelajaran Numbered Heads Together (NHT) ini sangat sesuai jika dipadukan dengan metode diskusi dan pendekatanya adalah inquiri. Menurut Nanik kelebihan Model Number Heads Together adalah setiap siswa menjadi siap semua dan dapat melakukan diskusi mengajari siswa yang kurang pandai (Ibrahim, 2000). Menurut Spencer Kagan (Maesuri, 2003), NHT merupakan struktur sederhana dan terdiri atas 4 tahap yang digunakan untuk mereview fakta-fakta dan informasi dasar yang berfungsi untuk mengatur interaksi para siswa. 
Atas dasar itulah penulis ingin mengkaji lebih mendalam terhadap masalah ini melalui suatu penelitian, sehingga ditetapkan judul penelitian tindakan kelas ini adalah "upaya meningkatkan hasil belajar kimia materi tata nama senyawa dan persamaan kimia melalui model Numbered Heads Together (NHT) pada siswa kelas X.1 SMA Negeri 1 Sungai Raya semester II tahun pelajaran 2014/2015".

Perubahan tingkah laku yang dapat diamati dari penampilan orang yang belajar adalah hasil belajar. Pada hakikatnya hasil belajar menunjukkan tingkat kemampuan siswa dalam mengikuti suatu proses pembelajaran. Tingkat kemampuan siswa dari hasil belajar ini dapat dilihat dari kemampuan kognitif, afektik dan psikomotorik (Bloom dalam Sutrisno, 2006). Senada dengan pendapat di atas Arikunto (Sutrisno, 2006) menyatakan bahwa hasil belajar merupakan sesuatu yang diperoleh dari dan sesudah kegiatan pembelajaran berlangsung. Hasil belajar ini dinyatakan dalam bentuk angka, huruf atau kata-kata baik, sedang dan kurang. Hasil belajar ini merupakan kemampuan aktual yang dapat diukur langsung melalui tes yang sesuai dengan tujuan pembelajaran.

Sehubungan dengan jenis-jenis kemampuan yang merupakan produk hasil belajar yang dikemukakan oleh Bloom di atas, Gagne (dalam Sutrisno, 2006) mengelompokkan hasil belajar menjadi lima kategori, yaitu : keterampilan intelektual, strategi kognitif, informasi verbal, keterampilan motorik, dan sikap. Kemampuan yang dikemukakan di atas harus sesuai dengan tujuan pembelajaran yang ditetapkan (Herdiansyah, 2009).

Reigeluth (dalam Sutrisno, 2006) menyatakan bahwa hasil belajar dipengaruhi oleh interaksi antara metode pengajaran dan kondisi pengajaran. Hal-hal yang termasuk metode pengajaran antara lain strategi pengorganisasian, strategi pengelolaan pembelajaran dan penyampaian. Selanjutnya hal-hal yang termasuk kondisi pengajaran adalah karakteristik siswa, karakteristik isi pengajaran, kendala pengajaran dan berbagai kondisi lain dalam proses pembelajaran. Secara umum ada tiga indikator keberhasilan belajar siswa, yaitu: (1) efektifitas pembelajaran, yang biasanya diukur dari tingkat keberhasilan siswa, (2) efisiensi pembelajaran, yang 
diukur dari waktu belajar, dan (3) daya tarik pembelajaran, yang biasanya diukur dari tendensi siswa yang ingin belajar terus menerus. Dari pernyataan ini dapat disebutkan bahwa hasil belajar merupakan suatu kinerja (performance) yang diindikasikan sebagai suatu kapabilitas (kemampuan) yang telah diperoleh.

Romizowski (dalam Sutrisno, 2006) menyatakan bahwa hasil belajar diperoleh dalam bentuk pengetahuan dan keterampilan. Pengetahuan dikelompokkan dalam empat kategori, yaitu: fakta, konsep, prosedur dan prinsip. Sedangkan hasil belajar dalam bentuk keterampilan dikelompokkan pada empat kategori, yaitu: keterampilan kognitif, akting, reaksi dan interaksi. Hasil belajar seperti ini menunjukkan tingkah laku atau kemampuan yang diharapkan dari siswa dalam bentuk keterampilanketerampilan dan konsep-konsep setealah proses pembelajaran.

Hasil belajar adalah kemampuan- kemampuan yang dimiliki siswa setelah ia menerima pengalaman belajarnya. Kingsley (Sudjana, 2001) membagi tiga macam hasil belajar, yaitu : (1) keterampilan dan kebiasaan; (2) pengetahuan dan pengertian; (3) sikap dan cita-cita yang masing-masing golongan dapat diisi dengan bahan yang ada pada kurikulum sekolah (Nana, Sudjana, 2001).

Pembelajaran kooperatif atau Cooperative learning mencakup suatu kelompok kecil siswa yang bekerja sebagai sebuah tim untuk menyelesaikan sebuah masalah, menyelesaikan suatu tugas, atau mengerjakan sesuatu untuk mencapai tujuan bersama (Suherman dalam Mufid, 2007). Pembelajaran koooperatif adalah pendekatan pembelajaran yang berfokus pada penggunaan kelompok kecil siswa untuk bekerja sama dalam memaksimalkan kondisi belajar untuk mencapai tujuan belajar.

Setiap manusia memiliki derajat potensi, latar belakang historis, serta harapan masa depan yang berbeda-beda. Karena perbedaan itulah manusia dapat saling asah, asih, dan asuh (saling mencerdaskan). Pembelajaran kooperatif dapat menciptakan interaksi yang saling asah, asih, dan asuh sehingga terciptalah masyarakat belajar (learning community). Siswa tidak hanya belajar dari buku, namun juga dari sesama teman. Pembelajaran 
kooperatif adalah pembelajaran yang secara sadar dan sengaja mengembangkan interaksi yang saling asuh untuk menghindari ketersinggungan dan kesalahpahaman yang dapat menimbulkan permusuhan, sebagai latihan hidup di masyarakat.

Unsur-unsur dasar pembelajaran kooperatif adalah sebagai berikut :

1) Siswa dalam kelompok haruslah beranggapan bahwa mereka "sehidup sepenanggungan bersama".

2) Siswa bertanggung jawab atas segala sesuatu di dalam kelompok, seperti milik mereka sendiri.

3) Siswa haruslah melihat bahwa semua anggota di dalam kelompok memiliki tujuan yang sama.

4) Siswa haruslah membagi tugas dan bertanggung jawab yang sama di antara anggota kelompok yang sama.

5) Siswa akan dikenakan evaluasi atau diberikan hadiah atau penghargaan yang juga akan dikenakan oleh anggota kelompok.

6) Siswa berbagi kepemimpinan dan mereka membutuhkan keterampilan untuk belajar bersama selama proses belajarnya.

7) Siswa akan diminta mempertanggungjawabkan secara individual materi yang ditangani dalam kelompok kooperatif (Ibrahim, 2000).

Manfaat diterapkannya strategi pembelajaran kooperatif menurut Linda Lundgren (Ibrahim, 2000) adalah sebagai berikut :

1) meningkatkan pencurahan waktu pada tugas,

2) rasa harga diri menjadi lebih tinggi,

3) memperbaiki kehadiran,

4) angka putus sekolah menjadi rendah,

5) penerimaan terhadap perbedaan individu menjadi lebih besar,

6) perilaku menganggu menjadi lebih kecil,

7) konflik antar pribadi berkurang,

8) sikap apatis berkurang,

9) pemahaman yang lebih mendalam,

10)motivasi lebih besar, 
11)hasil belajar lebih tinggi,

12)retensi lebih lama,

13)meningkatkan kebaikan budi, kepekaan, dan toleransi.

NHT merupakan pendekatan struktural pembelajaran kooperatif yang telah dikembangkan oleh Spencer Kagan, dkk (Ibrahim, 2000). Meskipun memiliki banyak persamaan dengan pendekatan yang lain, namun pendekatan ini memberi penekanan pada penggunaan struktur tertentu yang dirancang untuk mempengaruhi pola interaksi siswa. NHT adalah suatu pendekatan yang dikembangkan untuk melibatkan lebih banyak siswa dalam menelaah materi yang tercakup dalam suatu pelajaran dan mengecek pemahaman mereka terhadap isi pelajaran tersebut sebagai gantinya mengajukan pertanyaan kepada seluruh kelas (Ibrahim, 2000).

Model pembelajaran Numbered Heads Together (NHT) ini sangat sesuai jika dipadukan dengan metode diskusi dan pendekatanya adalah inquiri. Namun sebelumnya ada baiknya jika kita menyeleksi KD yang tepat untuk model pembelajaran ini. Setiap model dan metode yang kita pilih, tentu memiliki plus-minus sendiri-sendiri. Salah satu kekurangan dari model ini ialah kelas cenderung jadi ramai, dan jika guru tidak dapat mengkondisikan dengan baik, keramaian itu dapat menjadi tidak terkendali, sehingga menggangu proses belajar mengajar, tidak hanya di kelas sendiri, tetapi bisa juga mengganggu di kelas lain. (Herdiansyah, 2009).

Kelebihan Model Number Heads Together:

1) Setiap siswa menjadi siap semua

2) Dapat melakukan diskusi mengajari siswa yang kurang pandai Kelemahan Model Number Heads Together:

1) Kemungkinan nomor yang dipanggil, dipanggil lagi oleh guru

2) Tidak semua anggota kelompok dipanggil oleh guru (Nanik, 2011). 


\section{Tinjauan Materi Tata Nama Senyawa dan Persamaan Kimia}

\section{a. Tata nama senyawa}

Rumus kimia dapat ditulis dalam bentuk rumus molekul dan rumus empiris. Rumus molekul menggambarkan komposisi atom dalam suatu senyawa, sedangkan rumus empiris merupakan gambaran perbandingan jumlah atom dalam suatu senyawa. Tata nama senyawa kimia dapat digolongkan dalam dua kelompok besar yaitu : senyawa biner (terdiri dari dua unsur) dan senyawa terner (terdiri dari tiga atom) yang mengandung oksigen. Penamaan senyawa biner dimulai dari unsur pertama diikuti unsur kedua dengan menggunakan akiran -ida (Keenan et al, 1989). Senyawa biner dapat terdiri atas unsur logam dan non logam, atau non-logam dan non-logam. Senyawa terner sederhana meliputi asam, basa dan garam. Selain itu senyawa kimia juga dapat mengandung poliatom dan senyawa asam.

Senyawa biner logam dan non-logam dimulai dari nama kation logam dan diikuti nama anion non-logam. Logam dapat membentuk beberapa kation dengan muatan berbeda, maka muatan kationnya dinyatakan dengan angka Romawi. Penamaan senyawa biner dari dua non-logam mengkuti urutan berikut :

$$
\mathrm{B}-\mathrm{Si}-\mathrm{As}-\mathrm{C}-\mathrm{P}-\mathrm{N}-\mathrm{H}-\mathrm{S}-\mathrm{I}-\mathrm{Br}-\mathrm{Cl}-\mathrm{O}-\mathrm{F}
$$

Penamaan senyawa non logam-non logam

Nama senyawa biner dari dua jenis nonlogam adalah rangkaian nama kedua jenis unsur dengan akhiran ida pada nama unsur yang kedua.

Contoh:

- $\mathrm{HCl}=$ hidrogen klorida

- $\mathrm{H}_{2} \mathrm{~S}=$ hidrogen sulfida

Jika pasangan unsur yang bersenyawa membentuk lebih dari satu jenis senyawa, maka senyawa-senyawa itu dibedakan dengan menyebutkan angka indeks dalam bahasa Yunani sebagai berikut. 


$$
\begin{aligned}
1 & =\text { mono } & 6 & =\text { heksa } \\
2 & =\text { di } & 7 & =\text { hepta } \\
3 & =\text { tri } & 8 & =\text { okta } \\
4 & =\text { tetra } & 9 & =\text { nona } \\
5 & =\text { penta } & 10 & =\text { deka }
\end{aligned}
$$

Indeks satu tidak perlu disebutkan, kecuali untuk karbon monoksida.

\section{Contoh:}

- $\mathrm{CO}=$ karbon monoksida (awalan mono untuk $\mathrm{C}$ tidak perlu)

- $\mathrm{CO}_{2}=$ karbon dioksida

- $\mathrm{N}_{2} \mathrm{O}=$ dinitrogen oksida

- $\mathrm{NO}=$ nitrogen oksida

- $\mathrm{N}_{2} \mathrm{O}_{3}=$ dinitrogen trioksida

- $\mathrm{N}_{2} \mathrm{O}_{4}=$ dinitrogen tetraoksida

- $\mathrm{N}_{2} \mathrm{O}_{5}=$ dinitrogen pentaoksida

- $\mathrm{CS}_{2}=$ karbon disulfida

- $\mathrm{CCl}_{4}=$ karbon tetraklorida

Senyawa yang sudah umum dikenal tidak perlu mengikuti aturan di atas. Contoh:

- $\mathrm{H}_{2} \mathrm{O}=$ air

- $\mathrm{NH}_{3}=$ amonia

- $\mathrm{CH}_{4}=$ metana

Penamaan senyawa logam-non logam

Contoh:

- $\mathrm{NaCl}=$ natriumklorida

- $\mathrm{CaCl}_{2}=$ kalsium klorida

- $\mathrm{Na}_{2} \mathrm{SO}_{4}=$ natrium sulfat

- $\operatorname{Al}\left(\mathrm{NO}_{3}\right)_{3}=$ aluminium nitrat

Jika unsur logam mempunyai lebih dari satu jenis bilangan oksidasi, maka senyawa-senyawanya dibedakan dengan menuliskan bilangan oksidasinya, yang ditulis dalam tanda kurung dengan angka Romawi di belakang nama unsur logam tersebut. Contoh:

- $\mathrm{Cu}_{2} \mathrm{O}=$ tembaga(I) oksida

- $\mathrm{CuO}=$ tembaga(II) oksida

- $\mathrm{FeCl}_{2}=$ besi(II) klorida

- $\mathrm{FeCl}_{3}=$ besi(III) klorida

- $\mathrm{Fe}_{2} \mathrm{~S}_{3}=$ besi(III) sulfida

- $\mathrm{SnO}=\operatorname{timah}(\mathrm{II})$ oksida

- $\mathrm{SnO}_{2}=\operatorname{timah}(\mathrm{IV})$ oksida 
Senyawa ion yang mengandung poliatom dapat berupa kation poliatom atau anion poliatom. Untuk senyawa yang terdiri dari kation logam dan anion poliatom, maka penamaan dimulai dari nama kation logam diikuti nama anion poliatom. Penamaan senyawa yang terdiri dari kation poliatom dan anion monoatom/poliatom dimulai dari nama kation poliatom diikuti nama anion monoatom/poliatom.

Tabel 1. Beberapa Jenis Kation

\begin{tabular}{|l|c|l|l|l|l|}
\hline No. & Rumus & \multicolumn{1}{|c|}{ Nama Ion } & No. & Rumus & \multicolumn{1}{|c|}{ Nama Ion } \\
\hline 1. & $\mathrm{Na}^{+}$ & Natrium & 13. & $\mathrm{~Pb}^{2+}$ & Timbal(II) \\
2. & $\mathrm{~K}^{+}$ & Kalium & 14. & $\mathrm{~Pb}^{4+}$ & Timbal(IV) \\
3. & $\mathrm{Ag}^{+}$ & Argentum/Perak & 15. & $\mathrm{Fe}^{2+}$ & Besi(II) \\
4. & $\mathrm{Mg}^{2+}$ & Magnesium & 16. & $\mathrm{Fe}^{3+}$ & Besi(III) \\
5. & $\mathrm{Ca}^{2+}$ & Kalsium & 17. & $\mathrm{Hg}^{+}$ & Raksa(I) \\
6. & $\mathrm{Sr}^{2+}$ & Stronsium & 18. & $\mathrm{Hg}^{2+}$ & Raksa(II) \\
7. & $\mathrm{Ba}^{2+}$ & Barium & 19. & $\mathrm{Cu}^{+}$ & Tembaga(I) \\
8. & $\mathrm{Zn}^{2+}$ & Seng & 20. & $\mathrm{Cu}^{2+}$ & Tembaga(II) \\
9. & $\mathrm{Ni}^{2+}$ & Nikel & 21. & $\mathrm{Au}^{+}$ & Emas(I) \\
10. & $\mathrm{Al}^{3+}$ & Aluminium & 22. & $\mathrm{Au}^{3+}$ & Emas(III) \\
11. & $\mathrm{Sn}^{2+}$ & Timah(II) & 23. & $\mathrm{Pt}^{4+}$ & Platina(IV) \\
12. & $\mathrm{Sn}^{4+}$ & Timah(IV) & 24. & $\mathrm{NH}_{4}^{+}$ & Amonium \\
\hline
\end{tabular}

Tabel 2. Beberapa Jenis Anion

\begin{tabular}{|c|l|l|l|l|l|}
\hline No. & Rumus & Nama Ion & No. & Rumus & Nama Ion \\
\hline 1. & $\mathrm{OH}^{-}$ & Hidroksida & 16. & $\mathrm{C}_{2} \mathrm{O}_{4}{ }^{2-}$ & Oksalat \\
2. & $\mathrm{~F}^{-}$ & Fluorida & 17. & $\mathrm{PO}_{3}{ }^{3-}$ & Fosfit \\
3. & $\mathrm{Cl}^{-}$ & Klorida & 18. & $\mathrm{PO}_{4}{ }^{3-}$ & Fosfat \\
4. & $\mathrm{Br}^{-}$ & Bromida & 19. & $\mathrm{AsO}_{3}{ }^{3-}$ & Arsenit \\
5. & $\mathrm{I}^{-}$ & Iodida & 20. & $\mathrm{AsO}_{4}{ }^{3-}$ & Arsenat \\
6. & $\mathrm{CN}^{-}$ & Sianida & 21. & $\mathrm{SbO}_{3}{ }^{3-}$ & Antimonit \\
7. & $\mathrm{O}^{2-}$ & Oksida & 22. & $\mathrm{SbO}_{4}{ }^{3-}$ & Antimonat \\
8. & $\mathrm{~S}^{2-}$ & Sulfida & 23. & $\mathrm{ClO}^{-}$ & Hipoklorit \\
9. & $\mathrm{NO}_{2}{ }^{-}$ & Nitrit & 24. & $\mathrm{ClO}_{2}{ }^{-}$ & Klorit \\
10. & $\mathrm{NO}_{3}{ }^{-}$ & Nitrat & 25. & $\mathrm{ClO}_{3}{ }^{-}$ & Klorat \\
11. & $\mathrm{CH}_{3} \mathrm{COO}^{-}$ & Asetat & 26. & $\mathrm{ClO}_{4}{ }^{-}$ & Perklorat \\
12. & $\mathrm{CO}_{3}{ }^{2-}$ & Karbonat & 27. & $\mathrm{MnO}_{4}{ }^{-}$ & Permanganat \\
13. & $\mathrm{SiO}_{3}{ }^{2-}$ & Silikat & 28. & $\mathrm{MnO}_{4}{ }^{2-}$ & Manganat \\
14. & $\mathrm{SO}_{3}{ }^{2-}$ & Sulfit & 29. & $\mathrm{CrO}_{4}{ }^{2-}$ & Kromat \\
15. & $\mathrm{SO}_{4}{ }^{2-}$ & Sulfat & 30. & $\mathrm{Cr}_{2} \mathrm{O}_{7}{ }^{2-}$ & Dikromat \\
\hline
\end{tabular}


Tabel 3. Tana Nama Senyawa Politom

\begin{tabular}{|c|l|l|l|l|}
\hline No & Rumus Ion & Nama Ion & \multicolumn{1}{|c|}{ Rumus Senyawa } & \multicolumn{1}{|c|}{ Nama Senyawa } \\
\hline 1. & $\mathrm{NH}_{4}^{+}$ & ion amonium & $\mathrm{NH}_{4} \mathrm{Cl}$ & Amonium klorida \\
\hline 2. & $\mathrm{ClO}^{-}$ & ion hipoklorit & $\mathrm{NaClO}^{-}$ & Natrium hipoklorit \\
\hline 3. & $\mathrm{ClO}_{2}^{-}$ & ion klorit & $\mathrm{NaClO}_{2}$ & Natrium klorit \\
\hline 4. & $\mathrm{ClO}_{3}^{-}$ & ion klorat & $\mathrm{NaClO}_{3}$ & Natrium klorat \\
\hline 5. & $\mathrm{ClO}_{4}^{-}$ & ion perklorat & $\mathrm{NaClO}_{4}$ & Natrium perklorat \\
\hline 6. & $\mathrm{NO}_{2}^{-}$ & ion nitrit & $\mathrm{NaNO}_{2}$ & Natrium nitrit \\
\hline 7. & $\mathrm{NO}_{3}^{2-}$ & ion nitrat & $\mathrm{NaNO}_{3}$ & Natrium nitrat \\
\hline 8. & $\mathrm{SO}_{3}^{2-}$ & ion sulfit & $\mathrm{Na}_{2} \mathrm{SO}_{3}$ & Natrium sulfit \\
\hline 9. & $\mathrm{SO}_{4}^{2-}$ & ion sulfat & $\mathrm{Na}_{2} \mathrm{SO}_{4}$ & Natrium sulfat \\
\hline 10. & $\mathrm{C}_{2} \mathrm{H}_{3} \mathrm{O}_{2}^{-}$ & ion asetat & $\mathrm{NaC}_{2} \mathrm{H}_{3} \mathrm{O}_{2}$ & Natrium asetat \\
\hline 11. & $\mathrm{CO}_{3}^{2-}$ & ion karbonat & $\mathrm{Na}_{2} \mathrm{CO}_{3}$ & Natrium karbonat \\
\hline 12. & $\mathrm{~S}_{2} \mathrm{O}_{3}^{-2}$ & ion tiosulfat & $\mathrm{Na}_{2} \mathrm{~S}_{2} \mathrm{O}_{3}$ & Natrium tiosulfat \\
\hline 13. & $\mathrm{OH}$ & ion hidroksida & $\mathrm{NaOH}^{-}$ & Natrium hidroksida \\
\hline
\end{tabular}

\section{Tata nama senyawa asam dan basa}

Pernahkah kalian merasakan makanan asam? Makanan yang terasa asam antara lain dikarenakan mengandung cuka. Rasa asam dalam cuka berasal dari senyawa kimia yang dinamakan asam asetat $\left(\mathrm{CH}_{3} \mathrm{COOH}\right)$. Asam asetat hanyalah salah satu contoh senyawa kimia yang digunakan dalam kehidupan sehari-hari. Selain asam asetat, kita juga biasa menggunakan senyawa kimia lainnya, misalnya $\mathrm{NaOH}$ (natrium hidroksida) dan $\mathrm{NaCl}$ (natrium klorida).

Mengapa senyawa-senyawa tersebut mempunyai nama yang berbeda? Mengapa pula ada senyawa kimia yang digolongkan dalam senyawa asam, basa, dan garam? Menurut kalian, berdasarkan klasifikasi apakah penggolongan ke dalam senyawa asam, basa, dan garam? Nah temanteman, sekarang saatnya kalian perhatikan penjelasan berikut.

\section{$\checkmark$ Senyawa Asam}

Senyawa kimia seperti $\mathrm{HCl}, \mathrm{CH}_{3} \mathrm{COOH}$, dan $\mathrm{HBr}$ digolongkan senyawa asam karena saat hidrolisis menghasilkan ion $\mathrm{H}^{+}$. Dengan demikian, dapat disimpulkan bahwa suatu senyawa yang mengandung ion $\mathrm{H}^{+}$termasuk senyawa asam. Bagaimana aturan penamaan senyawa asam?

aturan penamaan pada senyawa asam adalah memberikan awalan asam (hidro) diikuti nama pasangannya dan akhiran -ida. Tetapi, ada juga yang hanya diberi awalan asam dan diikuti nama pasangannya tanpa akhiran -ida, seperti:

$$
\begin{array}{ll}
\mathrm{HNO}_{3} \longrightarrow \mathrm{H}^{+}+\mathrm{NO}_{3}^{-} & =\text {asam }+ \text { nitrat } ; \text { nama }=\text { asam nitrat } \\
\mathrm{HNO}_{2} \longrightarrow \mathrm{H}^{+}+\mathrm{NO}_{2}^{-} & =\text {asam }+ \text { nitrit } ; \text { nama }=\text { asam nitrit } \\
\mathrm{H}_{2} \mathrm{SO}_{4} \longrightarrow \mathrm{H}^{+}+\mathrm{SO}_{4}^{-} & =\text {asam }+ \text { sulfat } ; \text { nama }=\text { asam sulfat } \\
\mathrm{HCH}_{3} \mathrm{COO} \longrightarrow \mathrm{H}^{+}+\mathrm{CH}_{3} \mathrm{COO}^{-} \text {= asam + asetat } \text { nama } \text { = asam asetat }
\end{array}
$$




\section{$\checkmark$ Senyawa Basa}

Senyawa $\mathrm{KOH}$ dan $\mathrm{NaOH}$ dimasukkan dalam kelompok senyawa basa karena saat hidrolisis menghasilkan ion $\mathrm{OH}^{-}$. Jadi, ion $\mathrm{OH}^{-}$sebagai penanda bahwa suatu senyawa termasuk senyawa basa. Selain mengetahui penanda senyawa basa, kalian pasti juga ingin mengetahui aturan penamaan senyawa basa, bukan? Oleh karena itu, selesaikan soal-soal berikut.

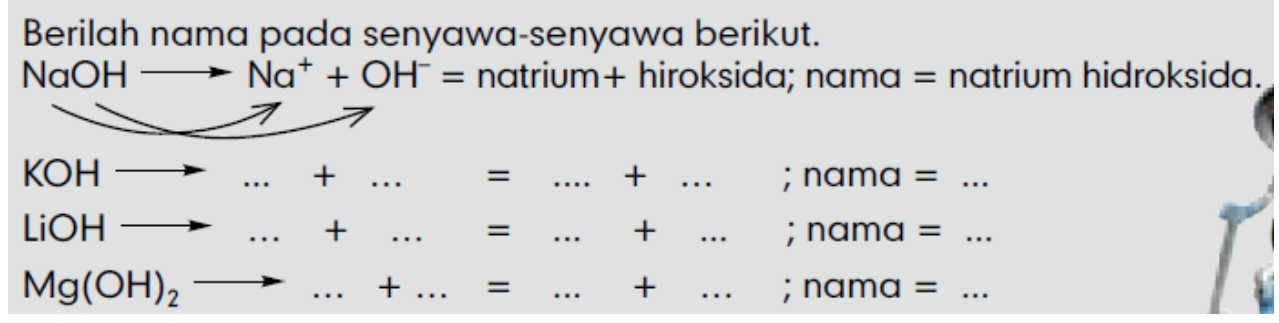

Berdasarkan uraian di atas, tentunya kalian bisa mengambil kesimpulan tentang aturan pemberian nama pada senyawa basa, bukan? Jadi, dapat disimpulkan bahwa penamaan senyawa basa dilakukan dengan menuliskan akhiran -hidroksida, setelah nama kationnya.

Tata nama trivial (perdagangan) pada senyawa kimia

Dalam kehidupan sehari-hari, kita sering mendengar istilah seperti asam cuka, urea, dan alkohol. Penamaan senyawa-senyawa tersebut tidak mengikuti kaidah/aturan dari IUPAC karena mengikuti tata nama dalam dunia perdagangan (trivial). Agar wawasan kalian semakin bertambah, perhatikan Tabel 2.4 berikut.

Tabel 4. Tata Nama IUPAC dan Trivial Pada Senyawa Kimia

\begin{tabular}{|c|l|l|l|}
\hline No. & \multicolumn{1}{|c|}{ Senyawa } & \multicolumn{1}{|c|}{ Nama IUPAC } & \multicolumn{1}{c|}{ Nama Trivial } \\
\hline 1. & $\mathrm{CH}_{3} \mathrm{COOH}$ & asam asetat & asam cuka \\
\hline 2. & $\mathrm{CH}_{3} \mathrm{CH}_{2} \mathrm{OH}$ & etanol & alkohol \\
\hline 3. & $\mathrm{CH}_{3} \mathrm{COCH}_{3}$ & propanon & aseton \\
\hline 4. & $\mathrm{HCHO}$ & formaldehida & formalin \\
\hline
\end{tabular}


Persamaan reaksi menggambarkan hubungan zat-zat kimia yang terlibat sebelum dan sesudah reaksi, baik secara kualitatif maupun kuantitatif. Zat yang berada di ruas kiri disebut pereaksi (reaktan) dan zat di ruas kanan dinamakan produk (hasil reaksi). Koefisien reaksi menyatakan jumlah partikel dari reaktan dan produk. Koefisien reaksi diberikan agar persamaan reaksi sesuai dengan hukum kekekalan massa dari Lavoiser, yaitu jumlah atom di ruas kiri sama dengan ruas kanan. Wujud zat dalam persamaan reaksi ada 4 jenis, yaitu padat (solid, s), cair (liquid, l), gas (g) dan larutan (aqueus, aq).

Tabel 5. Lambang, nama dan jumlah atom

\begin{tabular}{|c|c|c|c|}
\hline \multirow{3}{*}{ Rumus Kimia } & \multicolumn{2}{|c|}{ Jenis Unsur } & \multirow{2}{*}{ Jumlah Atom } \\
\cline { 2 - 4 } & Lambang Atom & Nama Atom & \\
\hline \multirow{3}{*}{$\mathrm{HCl}$} & $\mathrm{H}$ & Hidrogen & 1 atom \\
\cline { 2 - 4 } & $\mathrm{Cl}$ & $\mathrm{Klor}$ & 1 atom \\
\hline \multirow{3}{*}{$\mathrm{Ca}(\mathrm{OH})_{2}$} & $\mathrm{Mg}$ & Magnesium & 1 atom \\
\cline { 2 - 4 } & $\mathrm{O}$ & Oksigen & 2 atom \\
\cline { 2 - 4 } & $\mathrm{H}$ & Hidrogen & 2 atom \\
\cline { 2 - 4 } & $\mathrm{Ca}$ & Kalsium & 3 atom \\
\cline { 2 - 4 } & $\mathrm{P}$ & Pospor & 2 atom \\
\hline \multirow{3}{*}{$\mathrm{NaCN}^{*}$} & $\mathrm{O}$ & Oksigen & 8 atom \\
\cline { 2 - 4 } & $\mathrm{Na}$ & Natrium & 1 atom \\
\cline { 2 - 4 } & $\mathrm{C}$ & Nitrogen & 1 atom \\
\hline
\end{tabular}

\section{Contoh :}

1) $\mathrm{Ca}(s)+\mathrm{HCl}(a q) \longrightarrow \mathrm{CaCl}_{2}(a q)+\mathrm{H}_{2}(g)$ (reaksi salah, karena belum setara)

2) $\mathrm{Ca}(s)+\mathrm{HCl}(a q) \longrightarrow \mathrm{CaCl}_{2}(a q)+\mathrm{H}_{2}(g)$ (reaksi salah, karena belum setara)

3) $\mathrm{Ca}(s)+\mathrm{H}_{2} \mathrm{Cl}_{2}($ aq $) \longrightarrow \mathrm{CaCl}_{2}($ aq $)+\mathrm{H}_{2}(g)$ (menyalahi tata nama senyawa kimia)

4) $\mathrm{Ca}_{2}(s)+2 \mathrm{HCl}(a q) \longrightarrow 2 \mathrm{CaCl}(a q)+\mathrm{H}_{2}(g)$ (menyalahi tata nama senyawa kimia)

5) $\mathrm{Ca}(s)+2 \mathrm{HCl}(a q) \longrightarrow \mathrm{CaCl}_{2}(a q)+\mathrm{H}_{2}(g)$ (benar) 
Untuk mencapai keberhasilan dalam pembelajaran, guru harus dapat memilih metode pembelajaran yang tepat. Pendekatan pembelajaran inovatif yang dapat diterapkan guru sehingga dapat meningkatkan hasil belajar kimia sekaligus meningkatkan aktivitas siswa, serta memberi iklim yang kondusif dalam perkembangan daya nalar dan kreatifitas siswa adalah dengan pembelajaran kooperatif. Dengan pembelajaran kooperatif ini siswa termotivasi untuk belajar menyampaikan pendapat dan bersosialisasi dengan teman. Guru di sini hanya sebagai fasilitator dan motivator dalam pembelajaran.

NHT adalah tipe model pembelajaran kooperatif yang merupakan struktur sederhana dan terdiri atas empat tahap yang digunakan untuk mereview fakta-fakta dan informasi dasar yang berfungsi untuk mengatur interaksi siswa. NHT juga merupakan model pembelajaran yang dikembangkan untuk melibatkan lebih banyak siswa dalam menelaah materi. Selain itu NHT juga mendorong siswa untuk meningkatkan kerja sama antar siswa. Kerangka berpikir penelitian ini dapat di lihat pada Gambar.

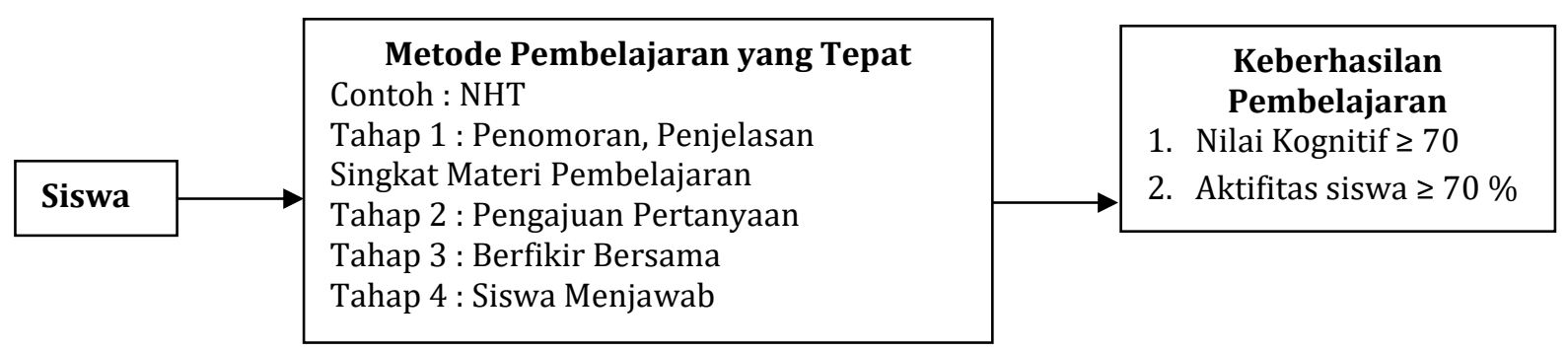

Gambar 1. Kerangka Berpikir Penelitian

Berdasarkan kerangka berpikir di atas, diharapkan model pembelajaran kooperatif tipe NHT dapat meningkatkan hasil belajar siswa pada materi tata nama senyawa dan persamaan kimia.

\section{B. METODE}

Penelitian tindakaan kelas ini dilakukan di kelas X.1, SMA Negeri 1 Sungai Raya, jalan Banda Aceh-Medan km. 415 Desa Birem Bayen, Kecamatan Sungai Raya, Kabupaten Aceh Timur. Waktu penelitian dilakukan selama 3 bulan yaitu mulai Maret 2015-Mei 2015. Waktu penelitian ini dilakukan di 
semester II tahun pelajaran 2014/2015. Waktu tatap muka pelajaran kimia untuk kelas X.1 adalah 2 jam pelajaran.

Subjek penelitian ini adalah siswa kelas X.1. Jumlah siswa kelas X.1 adalah 17 siswa, terdiri dari 6 siswa putra dan 11 siswa putri. Standar kompetensi (SK) yang digunakan untuk penelitian ini adalah memahami hukum-hukum dasar kimia dan penerapannya dalam perhitungan kimia (stoikiometri) dengan Kompetensi Dasar (KD) 2.1 yaitu mendeskripsikan tata nama senyawa anorganik dan organik sederhana serta persamaan reaksinya.

Desain penelitian ini menggunakan penelitian tindakan kelas (PTK) kolaboratif dengan model siklus yang dikemukakan oleh Kemmis dan Mc. Tanggart. Mereka mengemukakan dengan model siklus (putaran). Setiap siklus ada empat komponen penelitian tindakan yaitu perencanaan, tindakan, observasi, dan refleksi. Dalam prakteknya, prosedur penelitian ini adalah perencanaan, tindakan, observasi, refleksi dan evaluasi. Sistematika kerja penelitian tindakan kelas ini dapat dilihat pada Gambar 2 di bawah ini:.

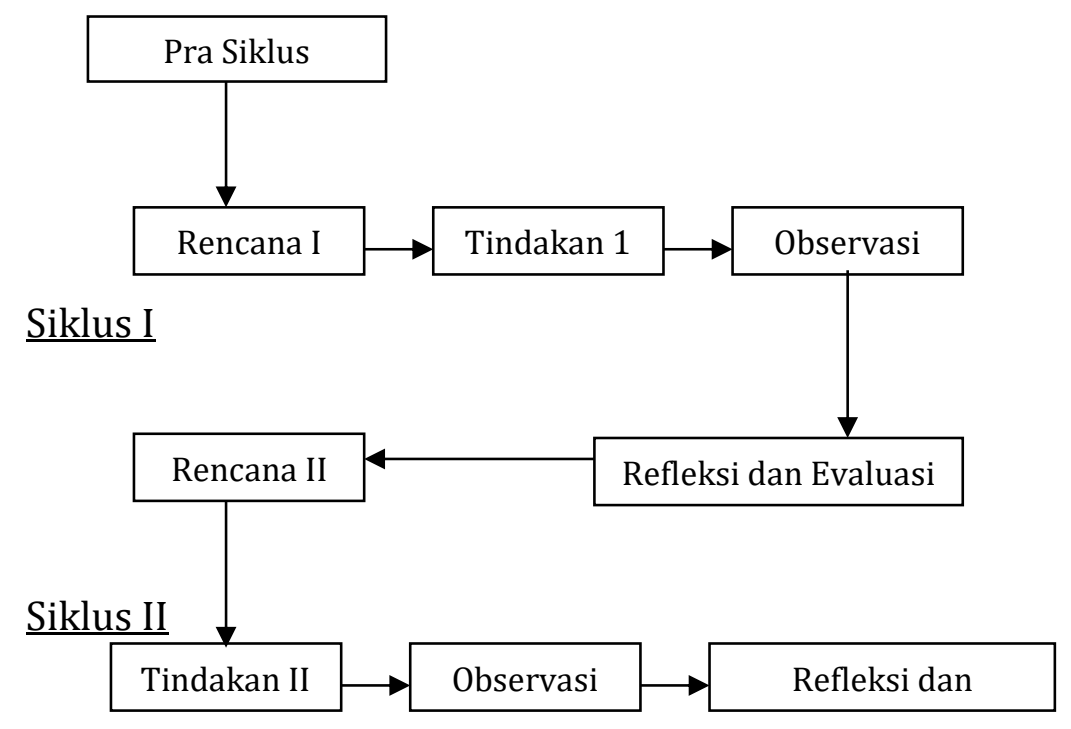

Gambar 2. Sistematika Kerja Penelitian

Penelitian ini merupakan penelitian tindakan kelas yang ditandai dengan adanya siklus, adapun dalam penelitian ini terdiri atas 2 siklus. Setiap siklus terdiri atas perencanaan, pelaksanaan, pengamatan dan refleksi.Teknik analisis data dalam penelitian tindakan kelas ini yaitu : 
> Hasil belajar siswa dianalisis dengan analisis diskriptif komparatif yaitu dengan membandingkan nilai tes antar siklus maupun dengan indikator keberhasilan.

Observasi aktivitas siswa dan guru saat kegiatan belajar mengajar dianalisis dengan analisis deskriptif berdasarkan hasil observasi dan refleksi.

Indikator yang digunakan untuk mengukur keberhasilan dalam penelitian tindakan kelas ini adalah sebagai berikut:

1. Apabila persentase siswa berkategori tuntas belajar minimal $70 \%$, dengan kriteria tuntas belajar adalah apabila nilai hasil evaluasi siswa pada siklus I dan II $\geq 70$.

2. Apabila aktivitas siswa dan guru dalam pembelajaran minimal $70 \%$ yang diukur dengan melihat lembar observasi siswa dan guru.

\section{HASIL DAN PEMBAHASAN}

\section{Deskripsi kondisi awal}

Siswa kelas X.1 SMA Negeri 1 Sungai Raya Kabupaten Aceh Timur merupakan kategori siswa yang memiliki pengusaan kognitif yang rendah berdasarkan pada nilai hasil tes seleksi penerimaan siswa baru tahun pelajaran 2014/2015. Hasil analisis nilai kognitif di semester ganjil tahun pelajaran 2014/2015 menunjukkan bahwa 75 \% tidak tuntas dan harus mengikuti remedial, hanya $25 \%$ yang sudah tuntas tapi hanya sebatas nilai standar minimal yang telah ditentukan. Hasil pengamatan penulis yang dilakukan selama proses pembelajaran berlangsung sebagian besar siswa mempunyai motivasi yang rendah dan kurang tertarik dengan pelajaran kimia. Sebelum pelaksanaan siklus I, peneliti melakukan wawancara dengan rekan sejawat yang mengajar di kelas X.1. Hasil wawancara dengan guru menunjukkan bahwa sebagian besar siswa belum memahami konsep tata nama senyawa dan persamaan kimia dengan baik. Hasil ulangan harian terakhir di kelas tersebut di peroleh data sebagai berikut : 3 siswa $(17,65 \%)$ telah memahami konsep dengan baik, 14 siswa (82,35 \%) belum memahami 
konsep tata nama senyawa dan persamaan kimia, sehingga nilai hasil belajarnya masih di bawah standar kelulusan.

\section{Hasil Penelitian Siklus I}

Berdasarkan hasil penelitian pada siklus I diperoleh 10 siswa (58,82\%) tuntas, dan 7 siswa $(41,18 \%)$ yang tidak tuntas. Pada siklus ini siswa sudah sangat antusias dalam proses pembelajaran dengan pembelajaran kooperatif (cooperative learning) model NHT. Setiap kelompok bersemangat untuk melakukan kegiatan mencari jawaban, mendiskusikan jawaban, dan memecahkan masalah dalam kelompok. Setiap kelompok dapat menyelesiakan tugas kelompoknya sesuai dengan waktu yang telah ditentukan. Setiap kelompok dapat mempresentasikan hasil kerja dan diskusi kelompoknya di depan kelas. Walaupun sudah terjadi kenaikan seperti tersebut di atas, namun hasil tersebut belum optimal. Kegiatan refleksi yang dilakukan dalam bentuk musyawarah tim peneliti juga menghasilkan beberapa masukan yaitu kerjasama siswa di dalam kelompoknya agar lebih ditingkatkan dan siswa tidak perlu gugup dalam menjawab soal-soal evaluasi di depan kelas. Oleh karena itu, diperlukan upaya perbaikan pembelajaran pada siklus II.

\section{Hasil Penelitian Siklus II}

Pada Siklus II, kemampuan siswa mengalami peningkatan, jumlah siswa yang tuntas meningkat yaitu sebanyak 15 siswa $(88,24 \%)$ sedangkan yang tidak tuntas hanya 2 siswa $(11,76 \%)$. Berdasarkan hasil pengamatan teman sejawat, motivasi belajar siswa sudah meningkat. Kegiatan pembelajaran sudah optimal dan keterlibatan siswa dalam pelajaran meningkat. Berdasarkan data observasi siswa dan guru maka model NHT berhasil meningkatkan hasil belajar siswa kelas X1 SMA Negeri 1 Sungai Raya Kabupaten Aceh Timur tahun pelajaran 2014/2015 pada materi tata nama senyawa dan persamaan kimia. Maka penelitian ini diakhiri sampai siklus II. Agar lebih jelas gambaran perbandingan peningkatan hasil kemampuan dari 
kondisi awal, Siklus I dan Siklus II, dapat dilihat dan diperhatikan pada rekapitulasi tabel dan grafik di bawah ini.

Tabel 6. Rekapitulasi Ketuntasan Belajar Setiap Siklus

\begin{tabular}{|c|c|c|c|c|c|c|c|c|c|c|}
\hline \multirow{2}{*}{ NO } & \multirow{2}{*}{ KRITERIA } & \multicolumn{3}{|c|}{ KONDISI AWAL } & \multicolumn{3}{c|}{ SIKLUS I } & \multicolumn{3}{c|}{ SIKLUS II } \\
\cline { 3 - 12 } & & JLH & KATEGORI & $\%$ & JLH & KATEGORI & $\%$ & JLH & KATEGORI & $\%$ \\
\hline \multirow{2}{*}{1} & NILAI $\geq 70$ & 3 & $\mathrm{~T}$ & 17,65 & 10 & $\mathrm{~T}$ & 58,82 & 15 & $\mathrm{~T}$ & 88,24 \\
\hline 2 & NILAI $\leq 70$ & 14 & TT & 82,35 & 7 & TT & 41,18 & 2 & TT & 11,76 \\
\hline \multicolumn{2}{|c|}{ JUMLAH } & 17 & & 100 & 17 & & 100 & 17 & & 100 \\
\hline
\end{tabular}

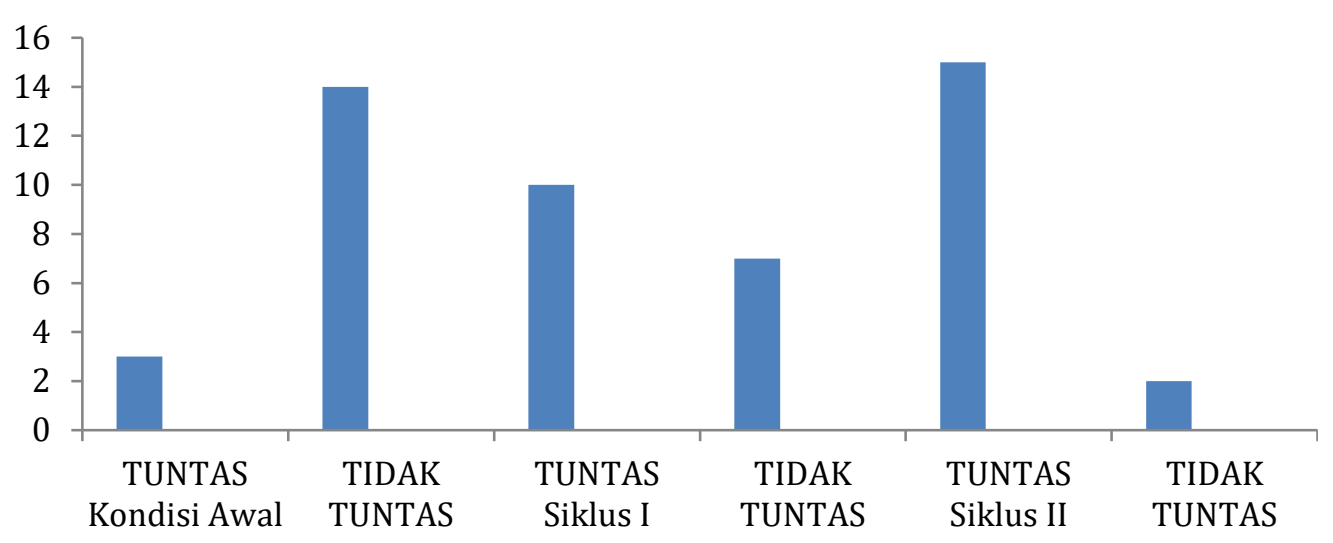

Gambar 3. Grafik Ketuntasan Belajar Siswa

Berdasarkan data rekapitulasi perbandingan pada tabel dan grafik di atas, diketahui bahwa pada kondisi awal siswa kelas X1 SMA yang tuntas hanya 3 siswa $(17,65 \%)$ yang tuntas, sedangkan sisanya sebanyak 14 siswa $(82,35 \%)$ tidak tuntas. Sedangkan pada Siklus I siswa yang tuntas mengalami peningkatan menjadi 10 siswa (58,82\%) tuntas, dan 7 siswa $(41,18 \%)$ tidak tuntas. Pada Siklus II kembali meningkat yaitu sebanyak 15 siswa $(88,24 \%)$ tuntas sedangkan yang tidak tuntas hanya 2 siswa $(11,76$ \%). Perkembangan keberhasilan pembelajaran yang diperoleh dapat di lihat pada Gambar di bawah ini. 


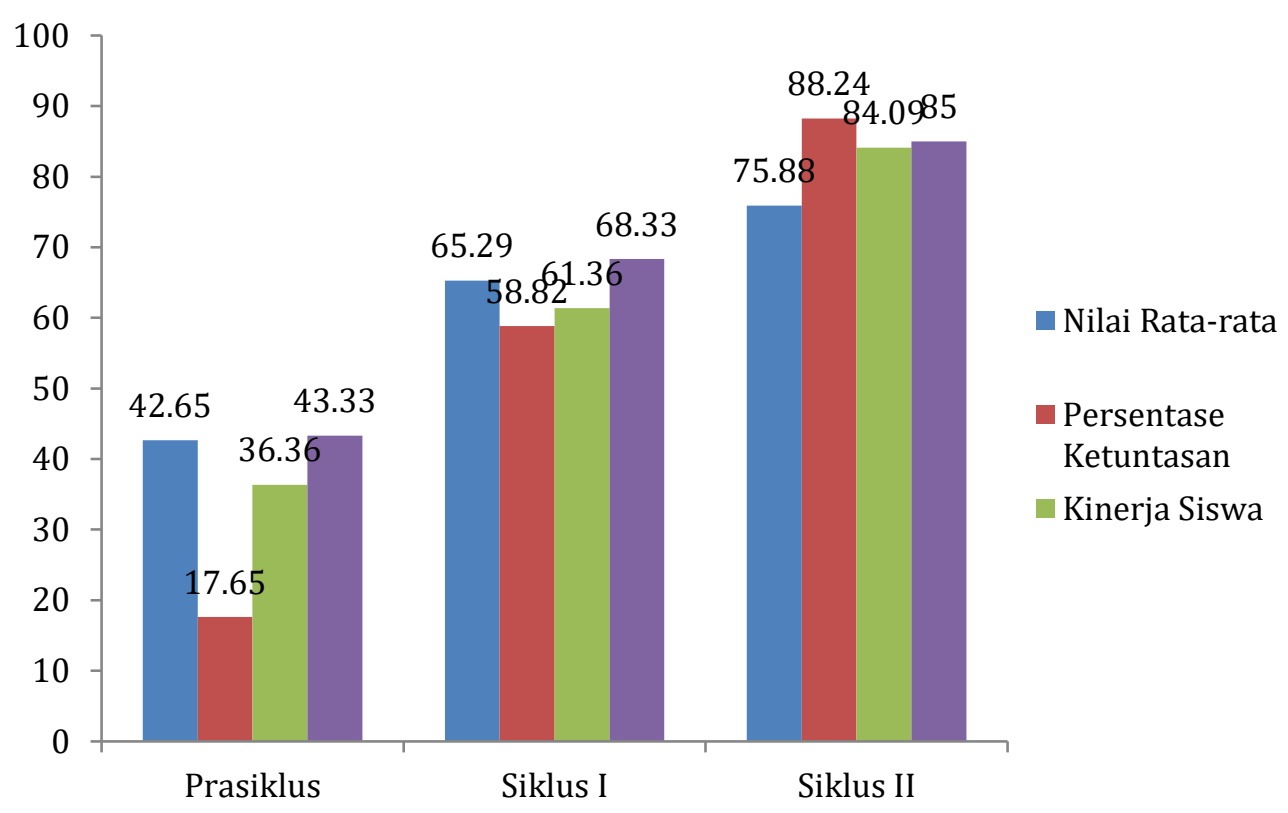

Gambar 2. Perkembangan Hasil Belajar Siswa Menggunakan Model NHT.

Dari Gambar 2 di atas terlihat adanya peningkatan atau kemajuan hasil pembelajaran siswa kelas X1 SMA Negeri 1 Sungai Raya Kabupaten Aceh Timur dalam pembelajaran kimia materi tata nama senyawa dan persamaan reaksi. Hal ini dikarenakan antusiasme dan motivasi siswa dalam mengikuti pembelajaran yang dilakukan secara kelompok sangat menantang dan menarik minat siswa.

\section{KESIMPULAN}

Berdasarkan hasil penelitian dan pembahasan diatas dapat disimpulkan sebagai berikut : Hasil belajar siswa di kelas X.1 semester II SMA Negeri 1 Sungai Raya Kabupaten Aceh Timur pada materi pokok tata nama senyawa dan persamaan kimia dapat ditingkatkan dengan model pembelajaran Numbered Heads Together (NHT), ditunjukkan oleh peningkatan nilai rata-rata siswa dari 65,29 pada siklus I menjadi 75,88 pada siklus II, dan ketuntasan belajar siswa meningkat dari 58,82\% pada siklus I menjadi 88,24\% pada siklus II. Aktivitas siswa di kelas X.1 semester II SMA Negeri 1 Sungai Raya pada materi pokok tata nama senyawa dan persamaan kimia dapat ditingkatkan melalui model pembelajaran NHT ditunjukkan oleh 
peningkatan nilai 61,36 \% pada siklus I menjadi 84,09 \% pada siklus II. Aktivitas guru di kelas X.1 semester II SMA Negeri 1 Sungai Raya pada materi pokok tata nama senyawa dan persamaan kimia dapat ditingkatkan melalui model pembelajaran NHT ditunjukkan oleh peningkatan nilai 68,33\% pada siklus I menjadi $85 \%$ pada siklus II.

\section{DAFTAR PUSTAKA}

Departemen Pendidikan Kebudayaan, 2014. Pembelajaran Kimia Melalui Pendekatan Saintifik. Jakarta: Depdikbud

Ernavita, 2004. Pedoman Khusus Pengembangan Silabus dan Penilaian Kurikulum 2004. Jakarta: Dirjendikdasmen.

Herdiansyah. 2009. Model Pembelajaran Cooperatif Tipe NHT. http://herdy07.wordpress.com/2009/04/22/model-pembelajaran nhtnumberes-head-together/.

Ibrahim,M.dkk.2000. Pembelajaran Kooperatif. Surabaya: University Press.

Maftuh, M. Dkk.2009. Penelitian Tindajan Kelas. Bandung. Yrama Widya.

Maesuri, Sitti. 2003. Makalah: Suatu Alternatif Model Pelatihan Lanjutan untuk Materi Penilaian Autentik. Jakarta: Direktorat PPDKA.

Mufid. M. 2007. Meningkatkan Hasil Belajar Matematika Pada Pokok Bahasan Operasi Hitung Bentuk Aljabar Melalui Model Pembelajaran Kooperatif Tipe Numbered Heads Together (NHT) Pada Siswa Kelas VII-A MTs Islamiyah Sumpiuh Banyumas Tahun Pelajaran 2006/2007. Skripsi. Semarang: FMIPA UNNES

Nanik. 2011. Numbered Heads Together. http://www.nanik.alunib.net/2011/01/model pembelajaran kooperatif tipe Numbered Heads Together/

Pettruci, Ralph H. 1985. Kimia Dasar.Jakarta: Erlangga 
